\title{
RISK MAPPING OF FIRES IN VEGETATION IN THE SERRA DO BRIGADEIRO STATE PARK (MG) AND SURROUNDINGS ${ }^{1}$
}

\author{
Fillipe Tamiozzo Pereira Torres ${ }^{2 *}$, Rafael Gomes Siqueira ${ }^{3}$, Gilberto Fialho Moreira ${ }^{4}$, Gumercindo \\ Souza Lima ${ }^{2}$, Sebastião Venâncio Martins ${ }^{2}$ and Sebastião Renato Valverde ${ }^{2}$
}

\footnotetext{
${ }^{1}$ Received on 25.05.2016 accepted for publication on 16.03.2017.

${ }^{2}$ Universidade Federal de Viçosa, Departamento de Engenharia Florestal, Viçosa, MG, Brasil. E-mail: <tamiozzo@ufv.br>, <gslima@ufv.br>,<venancio@ufv.br>and<valverde@ufv.br>.

${ }^{3}$ Universidade Federal de Viçosa, Graduado em Geografia, MG, Brasil. E-mail: <rafael.geo.siqueira@gmail.com>.

${ }^{4}$ Instituto Estadual de Florestas - Centro de Estudos e Desenvolvimento Florestal, Viçosa, MG, Brasil. E-mail: <cedef.ief@gmail.com>.

*Corresponding author.
}

\begin{abstract}
The aim of this study is to analyze the factors that affect the occurrence of fires in the vegetation, in the area of the Serra do Brigadeiro State Park (PESB) and its surroundings, and through this information to establish the most appropriate methodology to generate a risk map for fires in the place. A risk cartogram for fires was developed with the help of the ArcGIS 10.1 software, by the generation of maps of slope, aspects and land use. These maps were intercrossed, enabling the determination of the areas most susceptible to fires. Tested methodologies varied in the form of assigning grades to each predictor class of fire as well as in the division of risk classes. According to the results, the assignment of notes to each predictor class, depending on the size of the burned area and taking into account the history of events, reflected the risk of fires in vegetation in the region more satisfactorily.
\end{abstract}

Keywords: Map; Fire; GIS.

\section{MAPEAMENTO DO RISCO DE INCÊNDIOS EM VEGETAÇÃO NO PARQUE ESTADUAL DA SERRA DO BRIGADEIRO (MG) E ARREDORES}

\begin{abstract}
RESUMO - O objetivo deste estudo foi analisar os fatores que condicionam as ocorrências de incêndios em vegetação na área do Parque Estadual da Serra do Brigadeiro (PESB) e arredores, e através destas informações estabelecer a metodologia mais adequada para a geração de um mapa de risco de incêndios para o local. A elaboração do cartograma de risco de incêndios foi feita a partir do software ArcGIS 10.1, com a geração dos mapas de declividade, exposição das vertentes e de uso e cobertura do solo. Estes mapas foram intercruzados, possibilitando a determinação das áreas mais suscetíveis aos incêndios. As metodologias testadas variaram a forma de atribuição de notas para cada classe de previsão de incêndios, bem como a delimitação das classes de risco. De acordo com os resultados, a atribuição das notas de cada classe de previsão, em função do tamanho de sua área queimada, ou seja, levando-se em conta o histórico das ocorrências, refletiu mais satisfatoriamente o risco de incêndios em vegetação na região.
\end{abstract}

Palavras-chave: Mapa; Fogo; SIG.

Revista Árvore. 2017;41(4):e410409

http://dx.doi.org/10.1590/1806-90882017000400009 


\section{INTRODUCTION}

A forest fire is a significant and disturbing factor influencing the forest ecosystem, having a great impact on both biotic and abiotic conditions (Adámek et al., 2015).

With a consistent increase of pioneer species and loss of climax species in forests, a number of studies on trees in the Amazon and Southeast Asia have shown that fires have long-term effects on the composition of the vegetation (Barlow et al., 2012).

Also Camargos et al. (2010), in a study on the impact of fire on the regeneration stratum in a semideciduous seasonal forest stretch in Viçosa (MG), observed that there was a significant reduction in diversity before and after a fire, concluding that frequent fires on a major scale can severely alter the composition and structure of the forest fragments that favor species with a capacity for regrowth, to the detriment of the others.

According to Gralewicz et al. (2012), in the coniferous forests of Canada, even 20 years after a fire, the vegetation still seems to display its effect, showing a substantial reduction in the density and size as a whole and delaying the successional advancement in the affected area. This post-fire recovery process may be even slower in other regions, such as in Scandinavia, for example, where Drobyshev et al. (2012) observed the influence of fire even after 40 years of its occurrence.

The occurrence of fires is one of the continuous threats to the objectives of the Conservation Units (UCs) (Bonfim et al., 2003), especially in the remaining natural protected areas, intended mainly for the maintenance of biodiversity (Schiavetti et al., 2012). Even in Europe, the protected areas often cause a conflict in the local population. The reasons for these conflicts have been a lack of understanding and a lack of perceived benefits in the management plans in these areas, especially where traditional use coexists with different types of ownership and management (Fuentes-Santos et al., 2013).

In Brazil, in addition to these conflicts, the cause of fire in the Conservation Units has mainly been due to the incorrect use of fire for renovation of pastures and cleaning of crop residues in the neighboring properties (Bonfim et al., 2003), requiring a greater investment in policies aimed at reducing the impacts caused by fire.

With the limited amount of equipment and financial and human resources, forest managers must decide on the most efficient application of subsidies on actions, such as, prevention (e.g., environmental education campaigns), fuel management (e.g., prescribed burning and mechanical treatments), pre-suppression (e.g., planning and preparation, recruitment and training of firefighters, maintenance of fire and water points), and suppression and restoration measures (Mavsar et al., 2010).

In light of this, the impacts related to forest fires have generated an important discussion on the methodological possibilities of evaluation, control, and mitigation of these events. In this context, information technology has become increasingly important for monitoring the location of ignition points and for predicting the occurrence of fires and fire behavior. Improvements in the support systems and the quality of data obtained will result in decision-making that is more efficient in response to fires (Fuentes-Santos et al., 2013).

However, spatial analyses, based on geotechnology tools, present a potential little explored yet by those responsible for the elaboration and execution of public policies. However, with the popularization of these tools, these analyses should be promoted (Pereira et al., 2013). For the authors, a study of the spatial analyses on fires provides a visual perception of its distribution, allowing for the establishment of standards, as well as contributing significantly to the understanding of fire behavior.

A Geographic Information System (GIS) has the ability to collect, overlap, manipulate and visualize a large volume of data, which can be derived from the analysis of the possibility of igniting a forest fire, its potential for propagation, and related effects. It can also serve as a tool for coordinating with all those involved, who must take the necessary measures to defend against fire-related impacts, and it can also specify the location, time, and manner in which to carry out these measures (Vakalis et al., 2004).

However, these tools require specific information (topography, fuels, climate, etc.) from each region, to increase their efficiency. The relevance that the local level has for the success or failure of certain policies, 
implies that the principles and measures adopted will have to be adapted to the real and specific possibilities of intervention that derive from the particular territorial context (Galiana et al., 2013).

Therefore, the objective of this study is to analyze the factors that determine the occurrence of fires in the vegetation of the Serra do Brigadeiro State Park (PESB) and its surrounding areas, and through this information, establish an adequate method for the generation of a fire risk map for the location.

\section{MATERIALS AND METHODS}

The State Park of the Serra do Brigadeiro (PESB) is located in Zona da Mata (Minas Gerais, Brazil), in the municipalities of Araponga, Fervedouro, Miradouro, Ervália, Sericita, Pedra Bonita, Muriaé, and Divino. It has an area of 14,984 hectares, between meridians $42^{\circ} 20^{\prime}$ and $42^{\circ} 40^{\prime} \mathrm{W}$, and parallels $20^{\circ} 20^{\prime}$ and $21^{\circ} 00^{\prime} \mathrm{S}$. It is located at an elevation of the Serra da Mantiqueira, varying in altitude between 1,000 and 2,000 meters, with deep valleys and small plateaus, which exert an important influence on the climatic characteristics of the Park. The rainy season occurs between the months of November to March, which is also the hottest, and the driest period runs from April to September, with the quarter between June and August being the coldest (Paula et al., 2015).

The study area was expanded by 15,134 hectares, by generating a buffer of one kilometer from the limits of the UC, totaling 30,118 hectares.

The elaboration of the fire risk map was made using the software ArcGIS 10.1, with the cross-linking of information on the slope, aspect and land use.

To obtain the slope and aspect information, a Digital Altitude Model (DAM) was generated through interpolation of the contour lines, with a 20 meter equidistance and the quoted points were extracted from the four planialtimetric charts produced by the Instituto Brasileiro de Geografia e Estatística (IBGE) in the 1:50,000 scale (SF-23-X-B-V-2; SF-23-X-B-V-4; SF-23-X-B-VI1; SF-23-X-B-VI-3), which covered the study area. Before the generation of the model, it was necessary to perform a semi-automatic topological correction of the digital files with regard to the contour lines, aiming to connect the vectors in the adjacencies of the charts and adjust the lines in the places where overlaps of the curves were found. The spatial resolution used for DAM was 10 meters. This choice was based on the application of the graphical error, or tolerable graphical error (less graphic accuracy possible to be observed with the naked eye $-0.2 \mathrm{~mm}$ or $0.0002 \mathrm{~m}$ ), which allowed one to reach the spatial resolution of a raster through the scale of the input vector data or otherwise.

The information of land use was obtained through the photo interpretation of orbital images of the year 2011 , of the RapidEye constellation, with a five-meter resolution, whose codes were 2329425, 2329525, 2329526, and 2329626, obtained from the Secretary of State for Environment and Sustainable Development of Minas Gerais (SEMAD-MG). From these images the following classes were identified: Agriculture (agricultural crops), high altitude grasslands on rock (grassland on rock), high altitude grasslands on soil (grassland on soil), production forest (Eucalyptus), Semi-deciduous Seasonal Forest (native forest), and exotic grasses (pasture).

The 34 occurrences of fires recorded between 2007 and 2015, in a polygon format, were obtained from the Center for Forestry Studies and Development of the State Forestry Institute (CEDEF/IEF - MG), having as a source the Registry of Fire Occurrences (ROIs) of the Serra do Brigadeiro State Park.

For the mapping of fire susceptibility, four methodologies were tested in order to establish the one with greater efficiency for the study area.

\section{Methodology 1}

In the first analysis, notes were assigned to every bit of the information used, according to the study by Torres et al. (2014), for the municipality of Ubá (about 50 kilometers near the study area) (Table 1), where the influence of the factor was greater and to which the higher score was attributed. In this method the factor of greater impact received the note 10 , decreasing linearly until the factor of smaller impact.

The crosses, through the spatial interposition of the cartographic bases, also followed the proposal of Torres et al. (2014), where the crossing of land use (50\% weight) with the aspect (weight of $50 \%$ ) was initially performed; the product generated (weight $66 \%$ ) was crossed with the slope (weight 34\%) and this result (weight $75 \%$ ) was finally crossed with the access roads (weight 25\%). 
Table 1 - Table of scores assigned in the first and second methods of mapping risk of forest fires in the Serra do Brigadeiro State Park and surroundings.

Tabela 1 - Tabela de notas atribuidas nas primeira e segunda metodologias do mapeamento de risco de incêndios florestais no Parque Estadual da Serra do Brigadeiro e arredores.

\begin{tabular}{|c|c|c|c|}
\hline \multicolumn{2}{|l|}{ Land use } & \multicolumn{2}{|l|}{ Slope } \\
\hline Class & Notes & Class & Notes \\
\hline Pasture & 10 & $>40^{\circ}$ & 10 \\
\hline Grassland on soil & 9 & $30^{\circ}-40^{\circ}$ & 8 \\
\hline Grassland on rock & 8 & $20^{\circ}-30^{\circ}$ & 6 \\
\hline Eucalyptus & 7 & $10^{\circ}-20^{\circ}$ & 4 \\
\hline Agriculture & 5 & $0^{\circ}-10^{\circ}$ & 2 \\
\hline Native forest & 3 & \multicolumn{2}{|c|}{$\begin{array}{l}\text { Proximity of } \\
\text { access roads }\end{array}$} \\
\hline Aspect & & Class & Notes \\
\hline Class & Notes & $0-500 \mathrm{~m}$ & 10 \\
\hline North $\left(315^{\circ}-45^{\circ}\right)$ & 10 & $500-1000 \mathrm{~m}$ & 8 \\
\hline West $\left(225^{\circ}-315^{\circ}\right)$ & 8 & $1000-1500 \mathrm{~m}$ & 6 \\
\hline East $\left(45^{\circ}-135^{\circ}\right)$ & 6 & $1500-2000 \mathrm{~m}$ & 4 \\
\hline South $\left(135^{\circ}-225^{\circ}\right)$ & 4 & $2000-2500 \mathrm{~m}$ & 2 \\
\hline
\end{tabular}

Adapted from: Torres et al. (2014)

The risk classes were distributed according to the results of the software operations as follows: Null (0), very low (0.1 to 9), low (9.1 to 19$)$, medium (19.1 to 35$)$, high (35.1 to 57$)$, and very high $(>57)$.

\section{Methodology 2}

It is assumed that the extremely low risk class should comprise of the largest extension of the study area; and the size of the area covered by each class should decrease with increasing risk, reaching the highest risk class with the least extension of area included. This condition is related to the majority of the study area that had not observed the occurrence of fires (lower risk classes). On the other hand, the areas where the event is recurring (higher risk classes), are restricted when compared to the total area. Thus, in the second analysis, using the same notes assigned to the predictor classes in the first analysis (Table 1), the risk classes were distributed according to the product of mathematical operations (multiplication of the grades attributed to the mapped classes) carried out by the software depending on the area. Thus, arbitrarily, it was defined that $5 \%$ of all pixels that form the study area and present the highest values (product of the mathematical operations of crosses made by the software) would be classified as very high risk. The remaining $95 \%$ were progressively distributed in descending order $-9.5 \%$ of the following pixels with higher values were classified as high risk, the next $19 \%$ as medium risk, the consecutive $28.5 \%$ were classified as low risk, and the remaining $38 \%$ (which meant the areas with the lowest values obtained by mathematical operations) constituted the lowest risk class.

\section{Methodology 3}

In the third analysis, to analyze the influence of the history of fires on the occurrences, the polygons of the burned areas were superimposed on the information (class) predictors.

For the assignment of notes, two tests were performed; in the first, the notes were given as a function of the proportion of the area burned in each predictor class in relation to the total area of this predictor class; in the second test the notes were given as a function of the area burned in each predictor class in relation to the total burned area of the PESB.

For land use, aspect and slope, the first test was more consistent (the higher the susceptibility of the predicting class, the higher the percentage of burned area, for example, the greater the slope the greater the percentage of the area burned). Thus, note 10 was attributed to the predictive class, with the highest percentage of burned area being within its total area, and in proportion to this class, notes were attributed to the other predictor classes (Table 2). For the proximity to the access routes, the second test was more reliable (the closer to the access routes the greater the percentage of burned area) (Table 2). The distribution of the risk classes, in both cases, was made according to the first analysis.

\section{Methodology 4}

In the fourth analysis, the scores attributed to each predictor class were the same as those of the third analysis (Table 2), while the risk classes were distributed according to the second analysis.

\section{RESULTS}

During the study period, the 34 cases recorded, together burned $1,439.32$ hectares or $4.78 \%$ of the total area analyzed, of which 614.34 hectares were burned within the Park ( $4.1 \%$ of its total area) and 824.98 hectares in the surrounding area $(5.45 \%$ of the total buffer area). 
Table 2 - Award of notes according to the number of forest fires of each predictor class in the Serra do Brigadeiro State Park and surroundings between 2007 and 2015.

Tabela 2 - Atribuição de notas de acordo com o número de focos de cada classe preditora no Parque Estadual da Serra do Brigadeiro e arredores entre 2007 e 2015.

\begin{tabular}{|c|c|c|c|c|c|}
\hline \multicolumn{3}{|c|}{ Land use } & \multicolumn{3}{|c|}{ Slope } \\
\hline Class & $\% *$ & Notes & Class & $\% *$ & Notes \\
\hline Grassland on soil & 13.42 & 10 & $>40^{\circ}$ & $9.42 \%$ & 10 \\
\hline Grassland on rock & 10.17 & 8 & $30^{\circ}-40^{\circ}$ & $6.85 \%$ & 7 \\
\hline Native forest & 2.10 & 1 & $20^{\circ}-30^{\circ}$ & $5.21 \%$ & 5 \\
\hline Eucalyptus & 2.98 & 4 & $10^{\circ}-20^{\circ}$ & $3.80 \%$ & 4 \\
\hline Agriculture & 2.73 & 3 & $0^{\circ}-10^{\circ}$ & $2.65 \%$ & 3 \\
\hline Pasture & 2.72 & 2 & \multicolumn{3}{|c|}{ Proximity of access roads } \\
\hline \multicolumn{3}{|c|}{ Aspect } & Class & $\% * *$ & Notes \\
\hline Class & $\% *$ & Notes & $0-500 \mathrm{~m}$ & 42.38 & 10 \\
\hline North $\left(315^{\circ}-45^{\circ}\right)$ & 6.76 & 10 & $500-1000 \mathrm{~m}$ & 41.75 & 9 \\
\hline West $\left(225^{\circ}-315^{\circ}\right)$ & 5.49 & 8 & $1000-1500 \mathrm{~m}$ & 8.34 & 3 \\
\hline East $\left(45^{\circ}-135^{\circ}\right)$ & 3.60 & 6 & $1500-2000 \mathrm{~m}$ & 7.53 & 2 \\
\hline South $\left(135^{\circ}-225^{\circ}\right)$ & 3.46 & 5 & $2000-2500 \mathrm{~m}$ & 0 & 0 \\
\hline
\end{tabular}

* Percentage of the burned area of the predictor class in relation to the total area of the predicting class;

** Percentage of the burned area of each distance band in relation to the total burned within the PESB (1,439.32 ha).

According to the data of the burned area in each predicting class (Table 3 ), the grasslands (grasslands on soil and rock and pasture) was the hardest hit. It was also observed that the influence of relief (through its interactions with the climatological elements) favors the occurrences in areas on greater slopes. Although the burned area of the class $30^{\circ}$ to $40^{\circ}$ and $>40^{\circ}$ (Table 3 ) did not present the highest absolute values, the percentage of the burned area, in relation to the size of the area over these slopes, is higher in these classes (Table 2), where a quantitative reference was made to $16.30 \%$ of the areas above $30^{\circ}$ that were burned within the studied time cut. This percentage decreases in parallel with the decrease in the slope.

Regarding the distances of access routes, it can be observed in the PESB and surroundings, that the closer the distance to the access routes, the greater is the area that is burned. In the region, no fire was observed more than $2 \mathrm{~km}$ from a road and $84.13 \%$ of the area burned was less than $1 \mathrm{~km}$ (Table 3 ) away.

The four risk maps of vegetation fires produced, as well as the description of the classes of each can be observed in Figure 1 and Table 4.

\section{DISCUSSION}

The larger area burned from grassland on rock compared to grassland over soil may be related to the storage capacity of larger water in the soil, which makes it difficult to spread fire. Similar results have been found by Armenteras-Pascual et al. (2011), in Colombia, when comparing the size of the burned area according to the vegetation. They showed that the grassland vegetation was the type that was most burned, followed by capoeira, forests, and agricultural areas. The pattern for the number of occurrences was quite different however, the grassland vegetation again showed the highest value, followed by agricultural areas, forests, and capoeira. Also in Ubá (Torres et al., 2014) and Viçosa (Pezzopane et al., 2001), municipalities located in the Zona da Mata, Minas Gerais, about 50 kilometers away from the PESB, herbaceous vegetation presented a higher risk of occurrence.

According to Ganteaume and Jappiot (2013), this can be explained by the herbaceous vegetation being more influenced by the prevailing atmospheric conditions at a given time, which makes it drier than other plant typologies in a shorter period of time.

However, this pattern cannot be applied to any region. According to Gralewicz et al. (2012), in Canada, where $55.15 \%$ of the burned area is covered by forests, only a small number of fires occur in the grasslands, and there is typically collateral damage from forest fires.

In the Bohemian Switzerland National Park (BSNP), northwest Czech Republic, Adámek et al. (2015) concluded that fires are more frequent in areas - in descending order of importance: (1) Convex slopes 
Table 3 - Burned area in each predictor class in the Serra do Brigadeiro State Park and surroundings between 2007 and 2015.

Tabela 3 - Área queimada em cada classe preditora no Parque Estadual da Serra do Brigadeiro e arredores entre 2007 e 2015.

\begin{tabular}{|c|c|c|}
\hline \multirow{2}{*}{$\begin{array}{l}\text { Class } \\
\text { Land use }\end{array}$} & \multicolumn{2}{|c|}{ Burned area } \\
\hline & ha & $\%$ \\
\hline Eucalyptus & 6.84 & 0.48 \\
\hline Agriculture & 40.66 & 2.82 \\
\hline Pasture & 181.14 & 12.59 \\
\hline Native forest & 288.11 & 20.02 \\
\hline Grassland on soil & 429.37 & 29.83 \\
\hline Grassland on rock & 493.2 & 34.27 \\
\hline TOTAL & 1439.32 & 100.00 \\
\hline \multicolumn{3}{|c|}{ Aspect } \\
\hline South & 253.92 & 17.64 \\
\hline East & 299.51 & 20.81 \\
\hline West & 397.34 & 27.61 \\
\hline North & 488.55 & 33.94 \\
\hline TOTAL & 1439.32 & 100.00 \\
\hline \multicolumn{3}{|c|}{ Slope } \\
\hline $0-10^{\circ}$ & 151.38 & 10.52 \\
\hline $10^{\circ}-20^{\circ}$ & 386.46 & 26.85 \\
\hline $20^{\circ}-30^{\circ}$ & 411.4 & 28.58 \\
\hline $30^{\circ}-40^{\circ}$ & 286.99 & 19.94 \\
\hline$>40^{\circ}$ & 203.09 & 14.11 \\
\hline TOTAL & 1439.32 & 100.00 \\
\hline \multicolumn{3}{|c|}{ Proximity of access roads } \\
\hline $0-500 \mathrm{~m}$ & 609.96 & 42.38 \\
\hline $500-1000 \mathrm{~m}$ & 600.97 & 41.75 \\
\hline $1000-1500 \mathrm{~m}$ & 120.04 & 8.34 \\
\hline $1500-2000 \mathrm{~m}$ & 108.35 & 7.53 \\
\hline $2000-2500 \mathrm{~m}$ & 0 & 0.00 \\
\hline TOTAL & 1439.32 & 100 \\
\hline
\end{tabular}

with shallower sandy soils (higher evaporation rate) and vegetation with reduced crown density; (2) slopes with greater sun exposure; (3) areas with greater conifer abundance; (4) older forest areas (greater fuel accumulation and lower canopy density); and (5) areas close to villages, roads, tourist paths, and other places of human activity.

With respect to the fact that relief influences the process of fire propagation, the authors argue that in regions where the climate is more humid, the tendency is that the unevenness of the relief favors the occurrences of the fires. Corroborating, for Ganteaume and Jappiot (2013), several studies show that the probability of large fires is greater in areas of high topographic roughness, which may facilitate the occurrence and spread of fires and limit access to combat them.
Besides the topographic, this aspect also shows the climatic control over the occurrences. The exposed areas in the North are hotter and drier than the other exposed areas in the study region (Torres et al., 2014), due to their latitudinal position. The authors then highlight the west, east, and finally the south slopes, as less favorable to occurrences of fires, a sequence identical to that found in the PESB.

In the state of Amazonas, most of the forest affected by fires is also adjacent to roads (Vasconcelos et al., 2013). According to Gralewicz et al. (2012), in Canada, human accessibility was the main factor that increased the susceptibility to forest fires. Biotic and topographic factors were considered secondary. According to Keeley et al. (2004) and Stephens (2005), this condition can be explained by the fact that forest fires are caused by anthropic activities, as they are frequently observed along the transport corridors (tracks, highways, and railways).

This factor is so important that Ganteaume and Jappiot (2013) suggest that measures to reduce the threat of fires should first take into account the secondary road margins bordering grassland and pasture areas, thus providing a break of fuel in areas where fires are more likely to start and spread.

In Thailand, most of the fires occurred in a range of about 20 meters along either side of the main roads, and often spread to forest and agricultural land. This problem was reduced in 2000 by planting trees along the main roads (Hoare, 2004).

On the other hand, in Sweden, Drobyshev et al. (2012) observed that the development of a network of dense forest roads helped reduce the time interval between detection and initial attack by firefighters, which may have been one of the most important conditions for effective fire suppression, according to the authors.

Finally, analyzing the efficiency of the four methods tested (Table 4 and Figure 1), all four are adequate for the study area, however, some are more efficient than others. Regarding the percentage of the area burned, it is recommended that the lower the risk class, the greater its area of coverage. All methods presented this pattern, however, method 1 presented the lowest percentage of area in the low and very low classes $(61.80 \%)$ and higher in the high and high classes (16.34\%), while $81.78 \%$ of the PESB area was classified as low 
Table 4 - Areas of each risk class and burned areas in each class in the Serra do Brigadeiro State Park and surroundings. Tabela 4 - Areas de cada classe de risco e áreas queimadas em cada classe no Parque Estadual da Serra do Brigadeiro e arredores.

\begin{tabular}{|c|c|c|c|c|c|}
\hline \multirow[t]{2}{*}{ Risk } & \multicolumn{2}{|c|}{ Class area } & \multicolumn{2}{|c|}{ Area burned in each class } & \multirow{2}{*}{$\begin{array}{l}\% \text { of area burned in } \\
\text { relation to class area }\end{array}$} \\
\hline & ha & $\%$ & ha & $\%$ & \\
\hline \multicolumn{6}{|c|}{ Methodology 1} \\
\hline Very low & 10909.82 & 36.22 & 213.91 & 14.86 & 1.96 \\
\hline Low & 7703.03 & 25.58 & 288.75 & 20.06 & 3.75 \\
\hline Middle & 6583.26 & 21.86 & 432.55 & 30.05 & 6.57 \\
\hline High & 3523.67 & 11.70 & 340.89 & 23.68 & 9.67 \\
\hline Very high & 1398.63 & 4.64 & 163.22 & 11.34 & 11.67 \\
\hline TOTAL & 30118.41 & 100.00 & 1439.32 & 100.00 & \\
\hline \multicolumn{6}{|c|}{ Methodology 2} \\
\hline Very low & 11444.94 & 38.00 & 233.07 & 16.19 & 2.04 \\
\hline Low & 8583.76 & 28.50 & 325.91 & 22.64 & 3.80 \\
\hline Middle & 5722.43 & 19.00 & 429.82 & 29.86 & 7.51 \\
\hline High & 2861.18 & 9.50 & 252.61 & 17.55 & 8.83 \\
\hline Very high & 1506.1 & 5.00 & 197.91 & 13.75 & 13.14 \\
\hline TOTAL & 30118.41 & 100.00 & 1439.32 & 100.00 & \\
\hline \multicolumn{6}{|c|}{ Methodology 3} \\
\hline Very low & 21455.52 & 71.24 & 504.92 & 35.08 & 2.35 \\
\hline Low & 3174.22 & 10.54 & 175.77 & 12.21 & 5.54 \\
\hline Middle & 2872.26 & 9.54 & 311.69 & 21.66 & 10.85 \\
\hline High & 1888.76 & 6.27 & 307.31 & 21.35 & 16.27 \\
\hline Very high & 727.65 & 2.42 & 139.63 & 9.70 & 19.19 \\
\hline TOTAL & 30118.41 & 100.00 & 1439.32 & 100.00 & \\
\hline \multicolumn{6}{|c|}{ Methodology 4} \\
\hline Very low & 11444.99 & 38.00 & 211.56 & 14.70 & 1.85 \\
\hline Low & 8583.61 & 28.50 & 239.58 & 16.65 & 2.79 \\
\hline Middle & 5722.45 & 19.00 & 327.42 & 22.75 & 5.72 \\
\hline High & 2861.3 & 9.50 & 392.45 & 27.27 & 13.72 \\
\hline Very high & 1506.06 & 5.00 & 268.31 & 18.64 & 17.82 \\
\hline TOTAL & 30118.41 & $100.00 \%$ & 1439.32 & $100.00 \%$ & \\
\hline
\end{tabular}

or very low risk and only $8.69 \%$ classified as high or very high.

On the other hand, the third method was the one that presented the highest percentage of burned areas within the low and very low risk classes $(47.29 \%)$ and the lowest percentage of burned areas within the high and high risk classes (31.05\%).

However, method 3 indicates that it is the most efficient, because, according to the presented results, it was the one that presented the highest percentage of the area burned in relation to the area of high and very high risk classes, that is, $19.19 \%$ and $16.27 \%$, respectively, in relation to size of the areas classified as high and high risk, burned during the study period. From this perspective, method 4 was the one that presented the lowest percentage of burned area in relation to the size of the area for the lowest risk classes, $2.79 \%$ of the area classified as low risk, and only $1.85 \%$ of the area of very low risk was reached.

In short, the attribution of grades to each predicting class, according to the size of its burned area, that is, taking into account the history of occurrences in the place (which guided methods 3 and 4), reflected the risk of fires in vegetation in the region of Serra do Brigadeiro State Park more satisfactorily.

However, it is worth noting that this greater efficiency results from the use of the burned area polygon in other studies carried out in the municipalities of Ubá/MG (Torres et al., 2014) and Viçosa/MG (unpublished data). Going by the location of the fires obtained by satellites, method 1 was the most efficient, which indicates the need for further studies in relation 


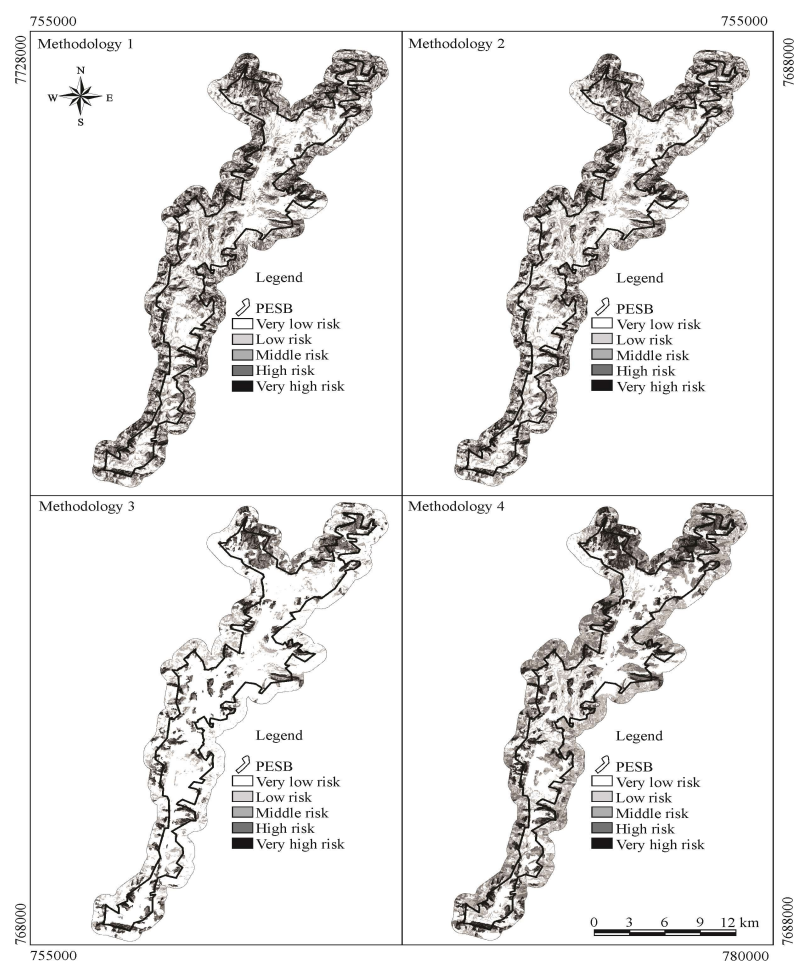

Figure 1 - Risk maps of vegetation fires in the Serra do Brigadeiro State Park and surroundings through 4 methodologies used.

Figura 1 - Mapas de risco de incêndios em vegetação no Parque Estadual da Serra do Brigadeiro e arredores obtidos através das 4 metodologias usadas.

to the assignment of notes to each predicting class, for the mapping of fire risk, according to the data used.

\section{CONCLUSIONS}

According to the results, it was concluded that in relation to soil cover the most affected classes were, in descending order: Altitude Grassland on rock, Altitude Grassland on soil, Semideciduous Seasonal Forest, exotic pastures, agricultural crops, and production forest (Eucalyptus). The characteristics of the local area controlled by climatic and topographic factors also showed an influence on the size of the burned area, as well as the aspect, which favored, in descending order, the slopes oriented to the north, west, east, and south; the higher the slope, the greater the percentage of burned area on the slope bands. The anthropic influence was also felt, as the closer one was to paths and roads, the greater the burned area was.
All the methods tested were adequate for the study area, however, the ones in which the notes of the predictor classes took into account the history of the occurrences (through the burned area polygons) showed a greater efficiency in relation to the others.

\section{REFERENCES}

Adámek M, Bobek P, Hadincová V, Wild J, Kopecký M. Forest fires within a temperate landscape: a decadal and millennial perspective from a sandstone region in Central Europe. Forest Ecology and Management, 2015;336:81-90.

Armenteras-Pascual D, Retana-Alumbreros J, Molowny-Horas R. Characterising fire spatial pattern interactions with climate and vegetation in Colombia. Agricultural and Forest Meteorology. 2011;151:279-89.

Barlow J, Parry L, Gardner TA, Ferreira J, Aragão LEOC, Carmenta R et al. The critical importance of considering fire in REDD+ programs. Biological Conservation. 2012;154:1-8.

Bonfim VR, Ribeiro GA, Silva E, Braga GM. Diagnóstico do uso do fogo no entorno do Parque Estadual da Serra do Brigadeiro (PESB), MG. Revista Árvore. 2003;27(1):87-94.

Camargos VL, Martins SV, Ribeiro GA, Carmos FMS, Silva AF. Avaliação do impacto do fogo no estrato de regeneração em um trecho de Floresta Estacional Semidecidual em Viçosa, MG. Revista Árvore. 2010;34(6):1055-63.

Drobyshev I, Niklasson M, Linderholm HW. Forest fire activity in Sweden: climatic controls and geographical patterns in 20th century. Agricultural and Forest Meteorology. 2012;154155:174-86.

Fuentes-Santos I, Marey-Pérez MF, GonzálezManteiga W. Forest fire spatial pattern analysis in Galicia (NW Spain). Journal of Environmental Management. 2013;128:30-42.

Galiana L, Aguilar S, Lázaro A. An assessment of the effects of forest related policies upon wildland fires in the European Union: applying the subsidiarity principle. Forest Policy and Economics. 2013;29:36-44. 
Ganteaume A, Jappiot M. What causes large fires in Southern France. Forest Ecology and Management. 2013;294:76-85.

Gralewicz NJ, Nelson TA, Wulder MA. Factors influencing national scale wildfire susceptibility in Canada. Forest Ecology and Management. 2012;265:20-9.

Hoare P. A process for community and government cooperation to reduce the forest fire and smoke problem in Thailand. Agriculture, Ecosystems and Environment. 2004;104:35-46.

Keeley JE, Fotheringham CJ, Moritz MA. Lessons from the 2003 wildfires in southern California. Journal of Forestry. 2004;102:26-31.

Mavsar R, Cabán AG, Farreras V. The importance of economics in fire management programmes analysis. In: Silva JS, Rego F, Fernandes P, Rigolo E, editors. Towards integrated fire management - outcomes of the European project fire paradox. Joensuu: European Forest Institute; 2010.

Paula TAR, Araújo GR, Deco-Souza T, Csemak Jr AC, Bergo LCF, Mantovani JE, et al. Aspectos do uso territorial por onça parda (Puma concolor), através de monitoramento via satélite, na região do Parque Estadual da Serra do Brigadeiro, MG. Arquivo Brasileiro de Medicina Veterinária e Zootecnia. 2015;67:80-8.

Pereira AA, Barros DA, Acerbi Jr, FW, Pereira JAA, Reis AA. Análise da distribuição espacial de áreas queimadas através da função $\mathrm{K}$ de Ripley. Scientia Forestalis. 2013;41(100):445-55.

Pezzopane JEM, Oliveira Neto SN, Vilela MF. Risco de incêndio em função da característica do clima, relevo e cobertura do solo. Floresta e Ambiente. 2001;8(1):167-6.

Schiavetti A, Magro TC, Santos MS. Implementação das Unidades de Conservação do corredor central da Mata Atlântica no Estado da Bahia: desafios e limites. Revista Árvore. 2012;36(4):611-23.

Stephens SL. Forest fire causes and extent on United States Forest Service lands. International Journal of Wildland Fire. 2005;14:213-22.

Torres FTP, Ribeiro GA, Martins SV, Lima, GS. Mapeamento da suscetibilidade a ocorrências de incêndios em vegetação na área urbana de UbáMG. Revista Árvore. 2014;38(5):811-7.

Vakalis D, Sarimveis H, Kiranoudis CT, Alexandridis A, Bafas G. A GIS based operational system for wildland fire crisis management II. System architecture and case studies. Applied Mathematical Modelling. 2004;28(4):411-25.

Vasconcelos SS, Fearnside PM, Graça PMLA, Nogueira EM, Oliveira LC, Fiqueiredo EO. Forest fires in southwestern Brazilian Amazonia: estimates of area and potential carbon emissions. Forest Ecology and Management. 2013;291(2013)199-208. 